University of Nebraska - Lincoln

DigitalCommons@University of Nebraska - Lincoln

Faculty Publications from the Harold W. Manter Laboratory of Parasitology

2003

Eimeria Species from Cryptotis Shrews (Insectivora: Soricidae) with Description of a New Species

\author{
Donald W. Duszynski \\ University of New Mexico, eimeria@unm.edu \\ Ralph P. Eckerlin \\ Northern Virginia Community College \\ Timothy J. McCarthy \\ Carnegie Museum of Natural History
}

Follow this and additional works at: https://digitalcommons.unl.edu/parasitologyfacpubs

Part of the Parasitology Commons

Duszynski, Donald W.; Eckerlin, Ralph P.; and McCarthy, Timothy J., "Eimeria Species from Cryptotis Shrews (Insectivora: Soricidae) with Description of a New Species" (2003). Faculty Publications from the Harold W. Manter Laboratory of Parasitology. 141.

https://digitalcommons.unl.edu/parasitologyfacpubs/141

This Article is brought to you for free and open access by the Parasitology, Harold W. Manter Laboratory of at DigitalCommons@University of Nebraska - Lincoln. It has been accepted for inclusion in Faculty Publications from the Harold W. Manter Laboratory of Parasitology by an authorized administrator of DigitalCommons@University of Nebraska - Lincoln. 


\title{
EIMERIA SPECIES FROM CRYPTOTIS SHREWS (INSECTIVORA: SORICIDAE) WITH DESCRIPTION OF A NEW SPECIES
}

\author{
Donald W. Duszynski, Ralph P. Eckerlin ${ }^{\star}$, and Timothy J. McCarthy† \\ Department of Biology, The University of New Mexico, Albuquerque, New Mexico 87131. e-mail: eimeria@unm.edu
}

\begin{abstract}
Fresh fecal samples from 12 shrews, 10 Cryptotis goodwini Jackson, 1933, and 2 Cryptotis merriami Thomas, 1898, were collected between December 1994 and May 1998; 11 (92\%) were positive for eimeriid coccidia, including 8 of $8 C$. goodwini and 2 of 2 C. merriami from Honduras and 1 of 2 C. goodwini from Guatemala. Two Eimeria species were found: 1 is consistent with the description of Eimeria whitakeri Upton and McAllister, 1991, and 1 is described in this study as new. Sporulated oocysts of the new species are subspheroidal, $16.8 \times 15.7(14-20 \times 15-19) \mu \mathrm{m}$, with a length-width (L/W) ratio of $1.1(1.0-1.2)$; they lack a micropyle and oocyst residuum, but 1-2 polar granules are always present. Sporocysts are elongate and ovoidal, $8.4 \times 6.0(6-10 \times 4.5-7.5) \mu \mathrm{m}$, with a L/W ratio of $1.4(1.2-1.7)$ and have a Stieda body and sporocyst residuum. This is the 49th Eimeria species described from all Insectivora but only the third from Cryptotis species.
\end{abstract}

The Insectivora is a medium-sized order ( 7 families, 66 genera, $\sim 428$ species) of eutherian mammals that range from the size of a baby mouse to that of a small rabbit (Yates, 1984; Nowak, 1991; Hutterer, 1993). These animals are characterized by a long narrow snout, primitive rooted teeth, small ears, and tiny eyes that sometimes lack external openings. Many are fossorial or semifossorial, and invertebrates constitute the bulk of the diet of most species, although some are known to eat small vertebrates, eggs of ground-nesting birds, fruits, nuts, and fungi. Recently, Duszynski and Upton (2000) summarized the world literature on the coccidia known from this mammalian order and identified and described the 48 valid Eimeria species. In collaboration with Mastozoología en el Núcleo de Centroamérica, a Central American network of field biologists in Belize, Guatemala, Honduras, and the United States, we had the opportunity to examine the feces of 2 rarely caught shrews (Cryptotis goodwini and Cryptotis merriami). In this study, we report the results of our observations on the coccidia found in these unique animals.

\section{MATERIALS AND METHODS}

Shrews were captured in plastic pitfalls, snap traps, and Sherman live traps. Further details of shrews and localities were reported by T. J. McCarthy et al. (pers. comm.). Fecal samples from all shrews were collected between December 1994 and May 1998 in Guatemala and Honduras. Feces were taken directly from the lower intestine and were placed in vials containing $2 \%(\mathrm{w} / \mathrm{v})$ aqueous potassium dichromate $\left(\mathrm{K}_{2} \mathrm{Cr}_{2} \mathrm{O}_{7}\right)$ solution, mixed thoroughly, and stored at ambient temperature for $\sim 2-3$ mo until they were received at the University of New Mexico (UNM) in the United States. On receipt at UNM, the samples were processed as detailed by Duszynski and Wilber (1997) and screened for coccidia. Oocysts were measured and photographed using both bright field and Nomarski differential interference contrast microscopy. Standardized abbreviations for oocyst-sporocyst structures are those used by Wilber et al. (1998) — oocyst characters: length (L), width $(\mathrm{W})$, their ranges and ratio $(\mathrm{L} / \mathrm{W})$, micropyle $(\mathrm{M})$, residuum $(\mathrm{OR})$, polar granules (PG); sporocyst characters: length (L), width (W), their ranges and ratio (L/W), Stieda body (SB), substieda body (SSB), parastieda body (PSB), residuum (SR), sporozoites (SP), refractile bodies (RB), and nucleus (N) in SP. All measurements are given in micrometers $(\mu \mathrm{m})$ with size ranges in parentheses following the means.

Received 2 December 2002; revised 13 March 2003; accepted 13 March 2003.

* Natural Sciences Division, Northern Virginia Community College, Annandale, Virginia 22003.

$\dagger$ Section of Mammals, Carnegie Museum of Natural History, Pittsburgh, Pennsylvania 15206.

\section{RESULTS}

Of the 12 shrews examined for coccidia, 11 (92\%) had eimerian oocysts in their feces, including 8 of $8 C$. goodwini and 2 of 2 C. merriami from Honduras and 1 of 2 C. goodwini from Guatemala (Table I).

\section{Eimeria whitakeri Upton and McAllister, 1991}

Description of sporulated oocyst: Oocyst shape, subspheroidal; number of walls, 2; wall thickness, 1.5-2.0; wall characteristics, outer, lightly sculptured or rough and brownish, inner, darker, $\sim 1 / 4$ of the total thickness; $\mathrm{L} \times \mathrm{W}(\mathrm{n}=71), 17.0 \times$ $15.5(15-20 \times 14-17) ; \mathrm{L} / \mathrm{W}$ ratio, 1.1 (1.0-1.3); $\mathrm{M}$ and OR, absent; PGs, present, large. Distinctive features of oocyst, thick wall and large PG.

Description of sporocyst and sporozoites: Sporocyst shape, ovoidal; $\mathrm{L} \times \mathrm{W}, 9.0 \times 6.0(7-11 \times 4.5-7.5) ; \mathrm{L} / \mathrm{W}$ ratio, 1.5 (1.2-1.8); SB, present; SSB, present, twice as wide as SB; PSB, absent; SR, present; SR characteristics, a cluster of mediumsized globules lying in the center between SP or to 1 side of sporocyst against wall; SP, lie head to tail and have a large RB located at their rounded end. Distinctive features of sporocyst, none.

\section{Taxonomic summary}

Type host: Cryptotis parva parva (Say, 1823), least shrew. Other hosts: Cryptotis goodwini Jackson, 1933.

Type locality: Johnson County, Texas, North America.

Geographic distribution: Texas, North America; Parque Nacional de Celaque, Departamento de Lempira, Honduras, Central America, $2,075 \mathrm{~m}\left(14^{\circ} 33^{\prime} \mathrm{N}, 88^{\circ} 40^{\prime} \mathrm{W}\right)$.

Prevalence: In 2 of 19 (10.5\%, original description) and 4 of 8 (50\%, this study) C. goodwini from Honduras and 1 of 2 C. goodwini from Guatemala; it was absent in both C. merriami from Honduras.

Sporulation: Exogenous (Upton and McAllister, 1991).

Prepatent and patent periods: Unknown.

Site of infection: Unknown. Oocysts recovered from feces.

Material deposited: Symbiotype host is deposited in the Section of Mammals, Carnegie Museum of Natural History, Pittsburgh, Pennsylvania (CM 112878). Photosyntypes (oocysts in $10 \%$ neutral buffered formalin) are deposited in the U.S. National Parasite Collection (USNPC), Beltsville, Maryland, No. 81476 (Upton and McAllister, 1991). 
TABLE I. Shrews (Cryptotis goodwini, and Cryptotis merriami) collected from various localities in Honduras and Guatemala, examined for coccidia, and found to be infected with Eimera whitakeri (E.w), Eimera hondurensis (E.h), or both species.

\begin{tabular}{|c|c|c|c|c|c|}
\hline Country/shrew spp. & Departamento & $\begin{array}{c}\text { Date } \\
\text { collected }\end{array}$ & $\begin{array}{l}\text { No. infected/ } \\
\text { no. collected } \\
(\%)\end{array}$ & $\begin{array}{l}\text { No. infected with } \\
1 \text { species }\end{array}$ & $\begin{array}{l}\text { No. infected with } \\
\text { both species }\end{array}$ \\
\hline \multicolumn{6}{|l|}{ Honduras } \\
\hline \multirow[t]{2}{*}{ C. goodwini } & Cortes & December 1994 & $2 / 2 \quad(100)$ & 2/2 (E.h) & NA* \\
\hline & Lempira & February 1998 & $6 / 6 \quad(100)$ & 5/6 (2 E.h, 3 E.w $)$ & $1 / 6$ \\
\hline \multirow[t]{2}{*}{ C. merriami } & Cortes & December 1994 & $1 / 1 \quad(100)$ & $1 / 1(E . h)$ & NA \\
\hline & Lempira & February 1998 & $1 / 1 \quad(100)$ & $1 / 1(E . h)$ & NA \\
\hline \multicolumn{6}{|l|}{ Guatemala } \\
\hline \multirow[t]{2}{*}{ C. goodwini } & Zacapa & April 1998 & $1 / 1 \quad(100)$ & NA & $1 / 1$ \\
\hline & El Progreso & May 1998 & $0 / 1$ & NA & NA \\
\hline 2 Countries/2 species & 4 Departments & & $11 / 12(92)$ & 9/11 Singly infected & 2/11 Multiply infected \\
\hline
\end{tabular}

$*$ NA $=$ not applicable.

\section{Remarks}

This species was first described by Upton and McAllister (1991), who found it in only 2 of 19 (10.5\%) C. parva parva they collected from 4 counties in north-central Texas. The oocysts they measured were $17.4 \times 16.4(15-19 \times 13-18.5)$ with a L/W ratio of $1.1(1.0-1.2)$, which are nearly identical in size to those observed by us. However, their sporocysts measured $11.2 \times 7.5(9.5-12 \times 6.5-8)$, with a $\mathrm{L} / \mathrm{W}$ ratio of $1.5(1.4-$ 1.6), whereas the sporocysts in $C$. goodwini from Honduras were slightly smaller, $9.0 \times 6.0(7-11 \times 4.5-7.5)$, but their L/ $\mathrm{W}$ ratio was the same, i.e., 1.5. All other qualitative features were identical between the oocysts studied by Upton and McAllister (1991) and those studied by us.

\section{Eimeria hondurensis n. sp.}

(Figs. 1-4)

Description of sporulated oocyst: Oocyst shape, spheroidal to subspheroidal; number of walls, 2; wall thickness, 1.2-2.0 (1.5); wall characteristics, outer, lightly pitted or sculptured giving a strongly striated appearance in optical cross section, inner, darker, only $\sim 1 / 4$ of total thickness; $\mathrm{L} \times \mathrm{W}(\mathrm{n}=59), 16.8 \times$ $15.7(14-20 \times 13-19) ; \mathrm{L} / \mathrm{W}$ ratio, $1.1(1.0-1.2) ; \mathrm{M}$ and $\mathrm{OR}$, absent; PGs, 1-2. Distinctive features of oocyst, strongly striated appearance of outer wall.

Description of sporocyst and sporozoites: Sporocyst shape, ovoidal; $\mathrm{L} \times \mathrm{W}, 8.4 \times 6.0(6-10 \times 4.5-7.5) ; \mathrm{L} / \mathrm{W}$ ratio, 1.4 (1.2-1.8); SB, nipplelike, present at pointed end; SSB, absent;
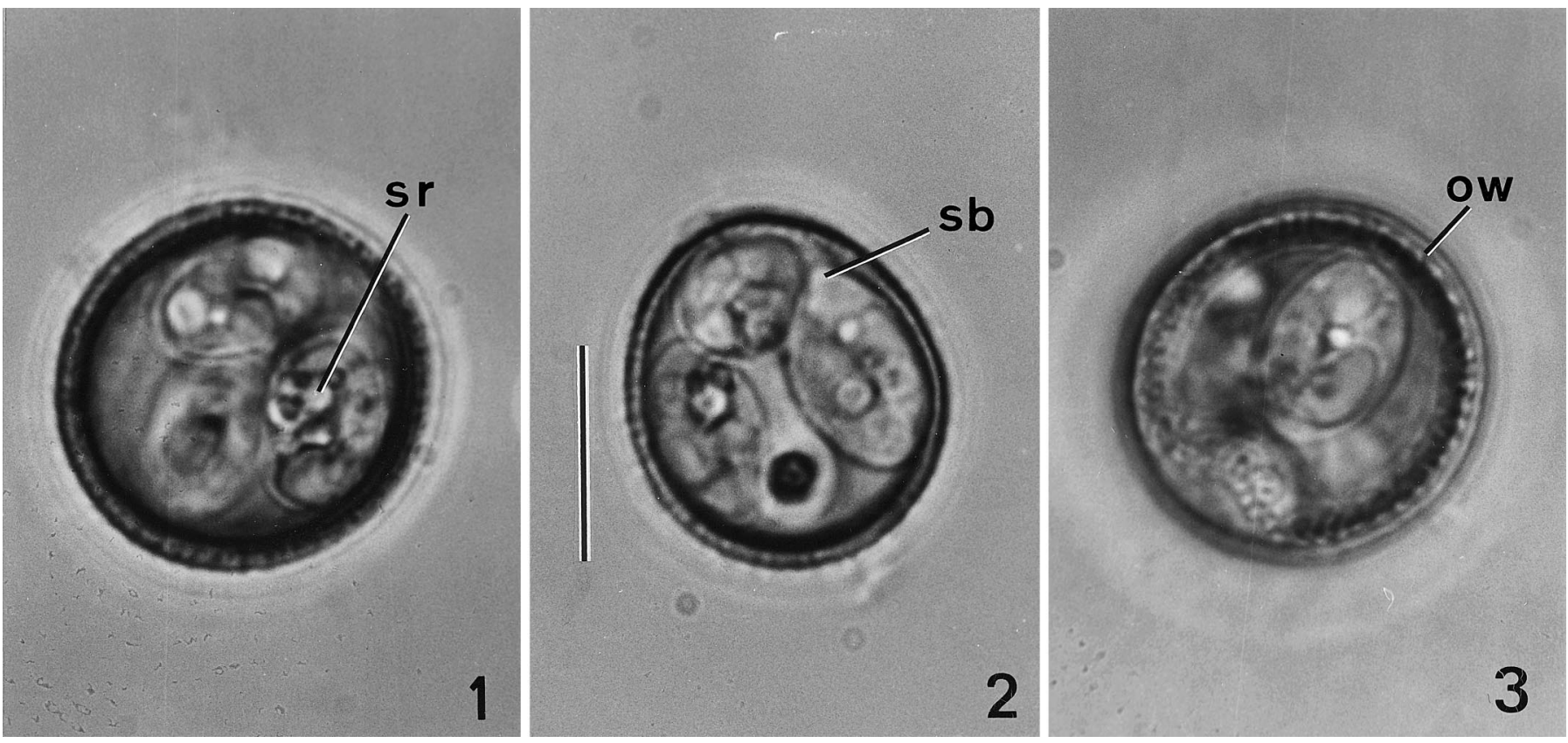

FiguRES 1-3. Photomicrographs of sporulated oocysts of Eimeria hondurensis from Cryptotis goodwini collected in Honduras. Bar $=10 \mu \mathrm{m}$ Note: Shape of oocyst and sporocyst and strongly striated oocyst wall; presence of a Stieda body and sporocyst residuum but absence of substieda body. Abbreviations: sb, Stieda body; sr, sporocyst residuum; ow, oocyst wall (striated). 


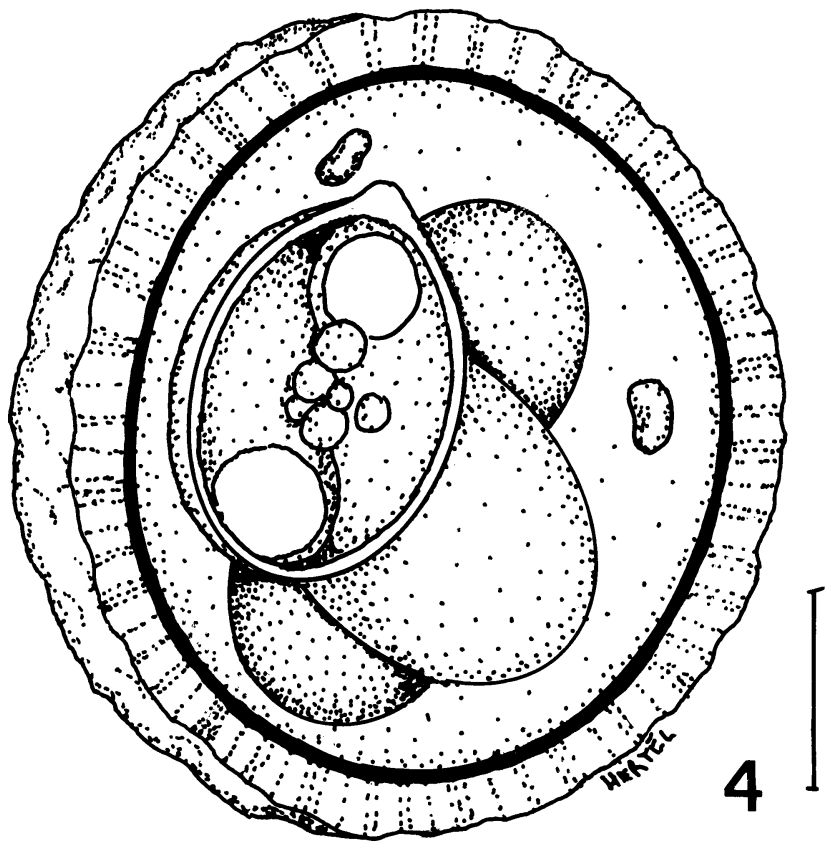

FIGURE 4. Line drawing of sporulated oocyst of Eimeria hondurensis. $\mathrm{Bar}=4 \mu \mathrm{m}$.

PSB, absent; SR, present; SR characteristics, a cluster of a few small and large globules lying in the center of sporocyst between SP or against sporocyst wall; SP, lie head to tail and have a posterior RB that varies in size. Distinctive features of sporocyst, nipplelike $\mathrm{SB}$.

\section{Taxonomic summary}

Type host: Cryptotis goodwini Jackson, 1933.

Other hosts: Cryptotis merriami Thomas, 1898.

Type locality: Campamento Don Tomás, Parque Nacional Celaque, Departamento de Lempira, Honduras, Central America, 2,075 m $\left(14^{\circ} 33^{\prime} \mathrm{N}, 88^{\circ} 40^{\prime} \mathrm{W}\right)$.

Other localities: Parque Nacional de Cusuco, Departamento de Cortes, Honduras, Central America; Reserva Biosfera de la "Sierra de las Minas," Departamento de Zacapa, Guatemala.

Geographic distribution: Guatemala, Honduras, Central America.

Prevalence: In 6 of 8 (75\%) C. goodwini from Honduras, 1 of $2(50 \%)$ C. goodwini from Guatemala, and 2 of $2(100 \%)$ C. merriami from Honduras.

Sporulation: Probably exogenous. Oocyst-fecal suspensions were kept in vials of $2 \%(\mathrm{w} / \mathrm{v})$ aqueous $\mathrm{K}_{2} \mathrm{Cr}_{2} \mathrm{O}_{7}$ solution for 2 mo at $\sim 24 \mathrm{C}$ before discovery and measurement.

Prepatent and patent periods: Unknown.

Site of infection: Unknown. Oocysts recovered from feces.

Material deposited: Symbiotype host deposited in the Section of Mammals, Carnegie Museum of Natural History, Pittsburgh, Pennsylvania (CM 112880). Photosyntypes of sporulated oocysts deposited in the USNPC, Beltsville, Maryland, No. 092569.00 (document 399).

Etymology: The nomen triviale is derived from the country and the Latin word ensis (belonging to).

\section{Remarks}

To date, there are only 2 other eimerians described from Cryptotis: Eimeria cryptotis McAllister and Upton, 1989, and E. whitakeri, described and discussed above. They are very similar in both mensural and qualitative features, and both are remarkably similar in the size of their sporulated oocysts (16.4 $\times 15.3$ [14-18 $\times 13-17]$ and $17.4 \times 16.4$ [15-19 $\times 13-18.5]$, respectively) to those of $E$. hondurensis (16.8 $\times 15.7$ [14-20 $\times$ 13-19]). Also, all 3 have identical L/W ratios of 1.1 and thick oocyst walls. However, the sporocysts of the other 2 described species are both larger $(10.6 \times 7.0[9-11 \times 6-8]$ and $11.2 \times 7.5$ [9.5-12 $\times 6.5-8]$, respectively) than those of $E$. hondurensis $(8.4 \times 6.0[6-10 \times 4.5-7.5])$, and E. hondurensis lacks a SSB, which the other 2 species possess.

\section{DISCUSSION}

There are now 49 valid species of Eimeria described from insectivores, but this must be only a small fraction of the species that actually parasitize potential hosts in this order. For example, of the 428 extant insectivore species on earth, only 38 species $(8.9 \%)$ have ever been examined for coccidia. In their seminal work on the coccidia of insectivores, Duszynski and Upton (2000) listed 75 valid eimeriid coccidia known to infect members of this host order including 48 Eimeria, 22 Isospora, and 5 Cyclospora species; on the basis of calculations from all insectivore species and their known coccidia, they estimated that there may be 1,200 coccidia species yet to be discovered!

Unfortunately, with so little known about these parasites at this time, few generalizations can be made. From the limited information provided in the summary by Duszynski and Upton (2000), it appears that insectivore coccidia species can be shared between members of the same genus but not between genera within the same family. Thus, it is not unexpected that E. whitakeri could be found in both C. parva in Texas and in C. goodwini in Honduras; likewise, it is not surprising to find E. hondurensis in C. goodwini from Guatemala and Honduras and in $C$. merriami from Honduras.

We note that all 3 Eimeria species described to date from Cryptotis species lack an oocyst residuum, but all possess sporocysts with Stieda bodies. These 2 morphologic structures are of interest because, recently, it has been shown that their presence or absence may be associated with different genetic lineages of coccidia (Barta et al., 1997; Zhao and Duszynski, 2001). Thus, these 3 eimerians may be genetically closely related.

Clearly, there is still much work to be done with the coccidia of not only shrews but also all other insectivores. Because oocysts can be collected easily in the field and represent the stage most used to date for the identification of coccidia, mammalogists, wildlife biologists, and all others who work with vertebrates can play a pivotal role in our understanding of the coccidia from their particular host group by properly collecting fecal samples to preserve oocysts (as outlined by Duszynski and Wilber, 1997).

\section{ACKNOWLEDGMENTS}

Principal field assistance was provided by J. O. Matson, N. Ordóñez G., and S. G. Pérez C. We are grateful to K. Greim-Felong for screening the samples and taking measurements and photomicrographs of sporu- 
lated oocysts and to L. Hertel for the line drawings. Consejo Nacional de Areas Protegidas and Defensores de la Naturaleza provided collecting permits for the Reserva Biofera de la Sierra de las Minas, and COHDEFOR arranged permits for Honduras. Fieldwork in 1994-1995 and 1998 was sponsored principally by the M. G. Netting Fund and the Mellon North American Mammal Institute of the Carnegie Museum of Natural History. Other financial support was provided by the National Geographic Society (grant 6105-98 to T.J.M.), the U.S. Food and Drug Administration Produce Safety Initiative (to R.P.E.), the Cecil Shuler Open Moment Fellowship from the Northern Virginia Community College Educational Foundation (to R.P.E.), and, in part, by the National Science Foundation Partnerships for Enhancing Expertise in Taxonomy grant, DEB-9521687 (to D.W.D.). For the use of the equipment, storage space, and other courtesies we thank the Section of Mammals, Carnegie Museum of Natural History, and the Museo de Historia Natural, Universidad de San Carlos de Guatemala. Eric Fernández hosted the 1998 base camp in Honduras. This article is a contribution from Mastozoologia en el Núcleo de Centroamérica.

\section{LITERATURE CITED}

Barta, J. R., D. S. Martin, P. A. Liberator, M. Dashkevicz, J. W Anderson, S. D. Feighner, A. Elbrecht, A. Perkins-Barrow, M. C. Jenkins, H. D. Danforth, M. D. Ruff, and H. Profous-JuCHELKA. 1997. Phylogenetic relationships among eight Eimeria species infecting domestic fowl inferred using complete small subunit ribosomal DNA sequences. Journal of Parasitology 83: 262-271.

Duszynski, D. W., AND S. J. Upton. 2000. Coccidia (Apicomplexa:
Eimeriidae) of the mammalian order Insectivora. Special Publication of the Museum of Southwestern Biology, No. 4. University of New Mexico Printing Services, Albuquerque, New Mexico, 67 p. , AND P. G. WILBER. 1997. A guideline for the preparation of species descriptions in the Eimeriidae. Journal of Parasitology 83: 333-336.

HuttereR, R. 1993. Order insectivora. In Mammal species of the world: A taxonomic and geographic reference, 2 nd ed., D. E. Wilson and D. A. M. Reeder (eds.). Smithsonian Institution Press, Washington, D.C., p. 69-139.

NowAK, R. M. 1991. Walker's mammals of the world, vol. I, 5th ed. Johns Hopkins Press Ltd., Baltimore, Maryland, 642 p.

Upton, S. J., AND C. T. MCAllister. 1991. Description of the oocysts of Eimeria whitakeri n. sp. (Apicomplexa: Eimeriidae) from least shrews, Cryptotis parva (Insectivora: Soricidae). Systematic Parasitology 20: 59-61.

Wilber, P. G., D. W. Duszynski, S. J. Upton, R. S. Seville, and J. O. CoRLISS. 1998. A revision of the taxonomy and nomenclature of the Eimeria spp. (Apicomplexa: Eimeriidae) from rodents in the Tribe Marmotini (Sciuridae). Systematic Parasitology 39: 113-135.

YATES, T. L. 1984. Insectivores, elephant shrews, tree shrews, and dermopterans. In Orders and families of recent mammals of the world, S. Anderson and J. K. Jones Jr. (eds.). John Wiley \& Sons, New York, p. 117-144.

Zhao, X., AND D. W. DusZYnsKi. 2001. Molecular phylogenies suggest the oocyst residuum can be used to distinguish two independent lineages of Eimeria spp. in rodents. Parasitology Research 87: 638643. 